\title{
Environmental Education of Senior High School Students
}

\author{
Harry S. Magluyan \\ University of Negros Occidental-Recoletos, Bacolod City, Philippines \\ harrymagluyan@gmail.com \\ https://orcid.org/0000-0003-4057-5565
}

\begin{abstract}
The social dimension of environmental issues communicates the worsening of environmental problems as a result of human decisions. This descriptivecomparative study evaluates environmental education in the areas of knowledge, awareness, attitudes, skills, and participation of 323 sampled senior high school students. Data were collected using a researcher-made survey questionnaire and were analyzed using mean, t-test, and ANOVA. The findings of the study showed students' high level of knowledge, attitude, skills, and participation. When grouped according to grade level and sex, significant differences were found in participation and in awareness when grouped according to grade level and strand. Consistently, a significant difference was found in the attitude when students were compared according to grade level, sex, and strand. Generally, this paper validates how knowledge and attitude affect human behavior towards the environment as mediated by appropriate environmental education. Likewise, it affirms that a positive attitude and concern towards the environment positively affects involvement in any environmental initiatives.
\end{abstract}

Keywords: Environmental Education, Knowledge, Awareness, Attitude, Skills, Participation, Descriptive-Comparative, Negros Occidental, Philippines 